\title{
Análise estilística da televisão brasileira
}

DOI: $10.1590 / 1809-58442019210$

\author{
João Paulo Hergesel ${ }^{1}$ \\ https://orcid.org/0000-0002-1145-0467
}

${ }_{1}^{1}$ (Universidade de Sorocaba, Pró-Reitoria de Pós-Graduação, Pesquisa, Inovação e Extensão, Programa de Pós-Graduação em Comunicação e Cultura. Sorocaba - SP, Brasil).

ROCHA, S. M. Estilo televisivo: e sua pertinência para a TV como prática cultural. Florianópolis: Insular, 2016.

Os estudos estilísticos direcionados à televisão ainda não tiveram seu apogeu enquanto metodologia, mas uma corrente aparentemente inoxidável tem se instaurado nesse sentido nos Estados Unidos e na Europa. Caldwell (1995), Butler (2002; 2010), Thompson (2003), Esquenazi (2010), Jacobs \& Peacock (2013) e Cooke (2013) são alguns autores que se dedicam a esse procedimento de análise. Suas observações, no entanto, costumam se voltar às séries ficcionais, o que acomete uma aproximação notória do que se conhece por estilística cinematográfica, cuja macrorreferência

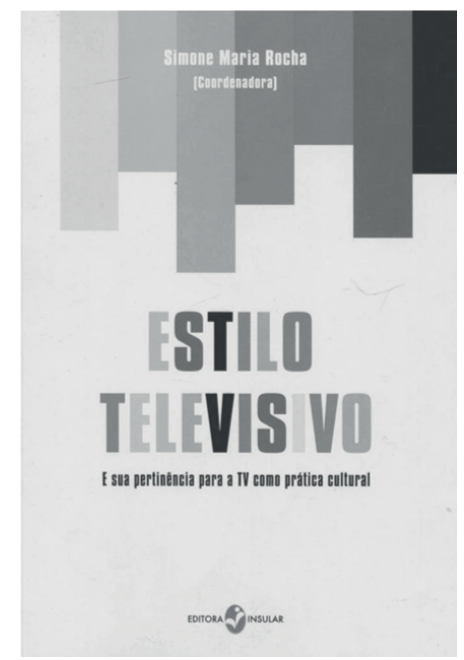
é Bordwell (2008; 2013). Em território brasileiro, pesquisas que enxergam a televisão como uma mídia carente de bibliografia própria ainda engatinham nesse itinerário metodológico, mas já é possível identificar no trabalho de Simone Maria Rocha uma matriz referencial.

Simone Maria Rocha é professora do Programa de Pós-Graduação em Comunicação Social da Universidade Federal de Minas Gerais, onde também realizou o estágio pós-doutoral. Tem doutorado em Comunicação e Cultura pela Universidade Federal do Rio de Janeiro (2003), mestrado em Sociologia pela Universidade Federal de Minas Gerais (1999) e graduação em Sociologia por esta mesma instituição (1997) e em Relações Públicas pela Pontifícia Universidade Católicas de Minas Gerais (1994). É a docente líder do Grupo de Pesquisa Comunicação e Cultura em Televisualidades (COMCULT) do PPGCOM/UFMG, cujas discussões resultaram em "Estilo televisivo: e sua pertinência para a TV como prática cultural”, lançado oficialmente durante o $14^{\circ}$ Encontro Nacional de Pesquisadores em Jornalismo - SBPJor, na Universidade do Sul de Santa Catarina (Unisul) - Campus Pedra Branca, realizado de 9 a 11 de novembro de 2016 no Município de Palhoça.

Os estudos compilados no livro têm como fundamento teórico o formalismo televisivo tratado por Butler (2010) e a defesa de Mittel (2004) sobre o gênero televisual como categoria 
da cultura. Juntamente dos demais autores compilados, a coordenadora, que assina a coautoria de todos os capítulos, baseia-se na ideia de que é por meio das técnicas cênicas e de edição que se define a atmosfera dos programas televisivos, o componente responsável por seduzir telespectadores e motivá-los a encontrar significações nas narrativas que se constroem.

Sustentando a ideia de que o estilo televisivo pode, em sua dimensão funcional, "denotar, expressar, simbolizar, decorar, persuadir, chamar ou interpelar, diferenciar, significar ao vivo” (ROCHA, 2016, p. 32), além de estar presente "na interseção de padrões culturais, econômicos, tecnológicos e de códigos semióticos/estéticos” (ROCHA, 2016, p. 34), as análises apresentadas direcionam para uma televisão que tende a contextualizar a realidade brasileira. O texto introdutório, bem como o primeiro capítulo são utilizados para nortear o leitor acerca dos objetivos do livro e das perspectivas de abordagens realizadas nos programas selecionados. A partir de então, a obra se divide em duas partes, sendo a primeira dedicada à permutação entre estilo televisivo e impacto cultural e a segunda visada a identificar os processos de categorização de gênero proporcionados pelo viés estilístico.

O primeiro objeto analisado, a telenovela Lado a Lado (Rede Globo), oferece uma visão de como o estilo aplicado à imagem e ao som pode dialogar com processos históricos, tendo como objeto de representação a Revolta da Vacina. Tal entrelaçamento entre história verídica e inventividade é revisto com a análise da telenovela Amor e Revolução (SBT), com foco dedicado à vinheta de abertura da trama. As discussões políticas e os modos como elas se representam no audiovisual se ampliam ao analisar a telenovela $O$ Rei do Gado (Rede Globo), em que se discutem questões como propriedade privada e coronelismo. O estudo seguinte, sobre a telenovela Saramandaia (Rede Globo), mostra como esse processo de crítica político-social se manifesta de maneira alegórica, por meio do chamado realismo maravilhoso. E as análises atravessam a fronteira ao analisar a série Sin Tetas No Hay Paraíso (Caracol TV), identificando enlaces com o processo de narcotráfico.

A segunda parte se inicia colocando em evidência as alterações estilísticas da telenovela Gabriela (Rede Globo), tomando como objeto de comparação as características tão associadas a esse gênero dramatúrgico. As séries de reportagem, classificadas como subgênero do telejornalismo, ganham destaque no capítulo seguinte, que observa o estilo aplicado no Jornal Nacional (Rede Globo), no Jornal da Band (Bandeirantes) e no Jornal da Record (Record TV) em matérias sobre o uso de entorpecentes. Ainda na linha da saúde, a análise seguinte é direcionada ao programa Bem-Estar (Rede Globo). Por fim, uma noção de mensurar a qualidade por meio do estilo é oferecida ao se analisar o telejornal Globo Rural (Rede Globo).

A leitura atenta da obra revela que a compreensão do estilo possibilita ao analista atuar como um produtor, buscando, primeiramente, entender o processo de elaboração de diversos produtos televisivos. Também torna o estudioso mais atento às sublimidades da programação, uma vez que destina o olhar para o conteúdo audiovisual que é veiculado e não somente à recepção, à repercussão, à audiência. Por fim, a obra, além de quebrar os paradigmas que associavam a ideia de estilo à de marca autoral/artística, ainda contribui para 
solidificar um dispositivo de análise para a televisão brasileira que auxilia nas investigações que desaguam na complexidade existente entre comunicação e sociedade, mídia e cultura.

\section{Referências}

BORDWELL, D. Figuras traçadas na luz: a encenação no cinema. Campinas: Papirus, 2008.

BORDWELL, D. Sobre a História do Estilo Cinematográfico. Campinas: Editora da Unicamp, 2013.

BUTLER, J. G. Television: Critical Methods and Applications. 2. ed. Mahwah: Lawrence Erlbaum Associates, 2002.

BUTLER, J. G . Television style. Nova Iorque: Routledge, 2010.

CALDWELL, J. T. Televisuality: style, crisis, and authority in American television. New Brunswick: Rutgers University Press, 1995.

COOKE, L. Style in British Television Drama. Hampshire; Nova Iorque: Palgrave Macmillan, 2013.

ESQUENAZI, J. P. Estilos e formas. In: ESQUENAZI, J. P. As séries televisivas. Lisboa: Texto \& Grafia, 2010, p. 121-136.

JACOBS, J.; PEACOCK, S. Television aesthetics and style. Nova Iorque; Londres: Bloomsbury, 2013.

MITTEL, J. Genre and television. Londres; Nova Iorque: Routledge, 2004.

THOMPSON, K. Storytelling in Film and Television. Cambridge (Massachusetts); Londres: Harvard University Press, 2003.

\section{João Paulo Hergesel}

Pesquisador de pós-doutorado com o projeto "Nuances poéticas nas narrativas midiáticas infantis e juvenis” (PPGCC/Uniso). Doutor em Comunicação (UAM), mestre em Comunicação e Cultura (Uniso) e licenciado em Letras (Uniso). Líder do grupo de estudos em Narrativas Midiáticas Infantis e Juvenis (Uniso/CNPq). Membro dos grupos de pesquisa Inovações e Rupturas na Ficção Televisiva Brasileira (UAM/CNPq) e Narrativas Midiáticas (Uniso/CNPq). Autor de "Estilo SBT de comunicar”, "Mídia, narrativa e estilo”, "Estilística aplicada à websérie”, entre outros livros acadêmicos e literários. E-mail: jp_hergesel@hotmail.com.

Este artigo é publicado em acesso aberto (Open Access) sob a licença Creative Commons Attribution Non-Commercial (CC-BY-NC), que permite uso, distribuição e reprodução em qualquer meio, sem restrições, desde que sem fins comerciais e que o trabalho original seja corretamente citado.

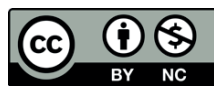

